Journal of Animal and Veterinary Advances 11 (19): 3575-3580, 2012

ISSN: $1680-5593$

(C) Medwell Journals, 2012

\title{
Analysis of Two Pit-1 Gene Polymorphisms and Relationships with Growth Performance Traits in Mink
}

\author{
Hongyan-Yang, Fangyong-Ning, Jing-Fu, Zhiheng-Du, Chunshan-Yang, \\ Chenggang-Liu and Xiujuan-Bai \\ Department of Animal Science, Northeast Agricultural University, 150030 Harbin, China
}

\begin{abstract}
The pit-1 has been implicated in regulation of body weight. Its gene sequence and protein function exhibit high evolutionary conservation and have been studied extensively in humans, mice, pigs and chickens. Mink pit-1 is nearly identical to dog pit-1 but little is know about its function. Thus, researchers investigated whether polymorphisms in th pit-1 exon 4 and exon6 were associated with mink growth traits. Five population of mink were assessed for growth traits for use in statistical correlation analysis with genomic sequence data. Two SNPs were detected in the pit-1 exon4 and exon6 of each population: $43 \mathrm{C}>\mathrm{T}$ and $143 \mathrm{~A}>\mathrm{G}$. The $43 \mathrm{C}>\mathrm{T}$ mutation produced three genotypes: $\mathrm{AA}, \mathrm{BB}$ and $\mathrm{AB}$. Statistical analysis of variance revealed that $43 \mathrm{C}>\mathrm{T}$ polymorphism was associated with Body Weight (BW) and Carcass Weight (CW) in black mink; the 143A $>\mathrm{G}$ mutation produced three genotypes as well: $\mathrm{CC}, \mathrm{DD}$ and $\mathrm{CD}$; statistcal analysis of variance revealed that the $134 \mathrm{~A}>\mathrm{G}$ polymorphism was associated Body Weight $(\mathrm{BW})$ in black mink $(\mathrm{p}<0.05)$. The interaction of $43 \mathrm{C}>\mathrm{T}$ and $143 \mathrm{~A}>\mathrm{G}$ was discussed through combination genotype analysis. The result showed that the combined genotype had significant association with Body Lenght (BL) in sapphire mink and Body Weight (BW) and Carcass Weigth $(\mathrm{CW})$ in black mink $(\mathrm{p}<0.05)$. The findings suggest that the pit-1 gene could be a qualitative trait locus or linked to a major gene that affects growth traits in mink.
\end{abstract}

Key words: Mink, pit-1 gene, polymorphism, combination genotype, growth traits

\section{INTRODUCTION}

Pit-1 (also named POUIF1 or GHF-1) is a member of the POU homeodomain family of transcription factors (Bodner et al., 1988; Ingraham et al., 1988) which regulates pituitary development and the expression of the growth hormone, prolactin and thyrotropin $\beta$-subunit genes (Cohen et al., 1996). Until now, Pit-1 encoding cDNAs were cloned in 18 species from three different Classes: Mammalia, Aves and Actinopterygii as summarized by Bastos et al. (2006). The human Pit-1 gene is located on chromosome $3 \mathrm{pl}$, the genomic sequence of this gene is $44.58 \mathrm{~kb}$ in size. The mRNA of Ccdl, $4803 \mathrm{bp}$ in length and it has 6 exons which encodes a protein of 472 amino acids (Ohta et al., 1992). Association studies have shown that Pit-1 is related to many production traits in domestic animals. HinfI polymorphism has been reported of the Bull pit-1 gene which revealed two alleles A and B (Renaville et al., 1997), the A allele was found to be superior for milk, protein yields and body depth; A Pit-1 gene mutations in humans have been reported as causing Combined Pituitary Hormone Deficiency (CPHD) with low or zero levels of TSH, growth hormone and prolactin (Cohen and Radovick, 2002). Genetic variations of Pit-1 gene are associated with body weight at 8 weeks of age indicating that the SNP in Pit-1 gene is a potential molecular marker for early growth rate in chicken (Jiang et al., 2004); Likewise, Qun et al. (2006) found that a 57 bp mutation in the intron 2 of chicken pit-1 gene was significantly associated with body weight $(\mathrm{p}<0.05)$, A PstI polymorphism at 3'UTR of goat Pit-1 gene was found by Lan et al. (2009), TT genotype was associated with superior cashmere yields in 2, 4 and 5 years old individuals as well as with average cashmere yield. These researchers considered that this SNP in Pit-1 gene is a potential molecular marker.

Little is known about the mink pit-1 gene, its biological function or nucleotide mutations that affect such. Taking into consideration the well-characterized features of pit-1 in other animals, it is reasonable to propose pit-1 involvement in the growth traits of minks. Therefore, researchers investigated the pit-1 gene sequences in five populations of mink to identify any Single Nucleotide Polymorphisms (SNPs) present in

Corresponding Author: Xiujuan-Bai, Department of Animal Science, Northeast Agricultural University, 150030 Harbin, China 
exon4 and exon6 to determine whether those SNPs were associated with desirable growth traits. Researchers expect the findings to provide novel insights into the mink pit-1 gene that will benefit future studies into this and other mink genotypes and support the development and application of molecular breeding.

\section{MATERIALS AND METHODS}

Experimental animals and phenotypic measurements: Genomic DNA samples were obtained from 240 individuals belonging to five populations: standardpitchy mink (121), sapphire mink (45), coffee mink (56), white mink (57) and black mink (60). All five populations were reared in the provinces of Liaoning Jinzhou mink breeding. Growth trait measurements included Body Weight (BW), Body Length (BL), Body Height (BH), Chest Circumference (CC), Abdomen Circumference (AC) and Carcass Weight (CW).

\section{DNA preparation, primer design and PCR amplification:} DNA samples were extracted from muscle were obtained from all minks which was extracted using standard methods. Isolated DNA from each mink was individually dissolved in sterile water to obtain a concentration of $50 \mathrm{ng} \mu \mathrm{L}^{-1}$ and stored at $-20^{\circ} \mathrm{C}$. The PCR primers were designed according to the dog pit-1 gene sequence deposited in GenBank (Accession No. NM001 006949.1). Three pairs of primers were designed and the sequences and size of the amplified fragments are shown in Table 1. PCR reaction mixtures $(25 \mu \mathrm{L})$ included $50 \mathrm{ng}$ of genomic DNA, $25 \mathrm{pmol}$ of each primer, $2.5 \mu \mathrm{L}$ $10 \times$ PCR buffer, $2 \mu \mathrm{L}$ dNTP and $1.5 \mathrm{U}$ Taq DNA polymerase. Thermal cycling conditions were showed in Table 2.

Table 1: The primers of PIT-1 gene

\begin{tabular}{lcc}
\hline Primers sequence $\left(5^{\prime} \rightarrow 3^{\prime}\right)$ & $\begin{array}{c}\text { Amplification } \\
\text { region }\end{array}$ & $\begin{array}{c}\text { Amplification } \\
\text { length }(\mathrm{bp})\end{array}$ \\
\hline $\begin{array}{l}\text { Pit-1-1F 5' CCCTTTACTTCGGCTGACA 3' } \\
\text { Pit-1-1R 5' GTTGGTGGCGTGGTTGGA 3' }\end{array}$ & exon1 & 117 \\
Pit-1-4F: 5' GATACACCCAAACCAACG 3' & exon4 & 150 \\
Pit-1-4R: 5' CTTCCTCCAGCCATTTAG 3' & & \\
Pit-1-6F: 5' TCAGACTTGTTTCACCC 3' & exon6 & 164 \\
Pit-1-6R: 5' TATTGCTGCTAAGGATGC 3' & & \\
\hline
\end{tabular}

PCR-Single Strand Conformation Polymorphism (SSCP) analysis and DNA sequencing: The PCR product was diluted 1:5 with loading buffer $(98 \%$ formamide, $10 \mathrm{mmol} \mathrm{L}^{-1}$ EDTA, $\mathrm{pH} \quad 8.0$, $0.025 \%$ xylene cyanol FF, $0.025 \%$ bromophenol blue and $2 \%$ glycerol).

After denaturation by incubation at $98^{\circ} \mathrm{C}$ for $10 \mathrm{~min}$, the mixture was immediately chilled on ice for $10 \mathrm{~min}$ and then loaded onto a $16 \%$ acrylamide/bisacrylamide (arc: bis, 29:1) gel.

Bands were resolved by electrophoresis at $10 \mathrm{~V} \mathrm{~cm}{ }^{-1}$ for $16 \mathrm{~h}$ and detected by using the Standard Silver Staining Method. For each polymorphism, three PCR products were amplified and purified. Sequencing was carried out by the ABI377 sequencer.

Statistical analysis: To determine associations between the SNPs and carcass traits, the PROC-GLM procedure in the SAS Statistical Software (Version 8.2) was used. The linear model was as follows:

$$
\mathrm{Y}_{\mathrm{i}}=\mu+\mathrm{G}_{\mathrm{i}}+\mathrm{e}
$$

Where:

$\mathrm{Y}=$ Growth traits

$\mu=$ Mean number of population

$\mathrm{G}_{\mathrm{i}}=$ The effect of genotype

$\mathrm{e}=$ The random error

The analysis model of combined genotype was as followed:

$$
\mathrm{Y}=\mu+\mathrm{G}(43 \mathrm{C}<\mathrm{T}+143 \mathrm{~A}<\mathrm{G})+\mathrm{e}
$$

Where:

$\mathrm{Y} \quad=$ The observed values of traits

$\mathrm{G} \quad=$ The genotype effect

$\mu \quad=$ The mean of the population

$\mathrm{G}(43 \mathrm{C}>\mathrm{T}$

and $143 \mathrm{~A}>\mathrm{G})=$ The combination genotype effect

e $\quad=$ The random error

The $\chi^{2}$-test was used to determine significant differences in allele frequencies. A $p<0.05$ was considered statistically significant.

Table 2: Parameters of PCR amplification

\begin{tabular}{lcllcc}
\hline Primers & Initial denaturation & Denaturation & Annealin & Elongation & Elongation \\
\hline Pit-1-1 & $94^{\circ} \mathrm{C}, 7 \mathrm{~m}$ & $94^{\circ} \mathrm{C}, 0 \mathrm{sec}$ & $55.5^{\circ} \mathrm{C}, 10 \mathrm{sec}$ & $72^{\circ} \mathrm{C}, 4 \mathrm{sec}$ & 36 \\
Pit-1-4 & $94^{\circ} \mathrm{C}, 5 \mathrm{~m}$ & $94^{\circ} \mathrm{C}, 30 \mathrm{sec}$ & $56.0^{\circ} \mathrm{C}, 35 \mathrm{sec}$ & $72^{\circ} \mathrm{C}, 30 \mathrm{sec}$ & 35 \\
Pit-1-6 & $94^{\circ} \mathrm{C}, 5 \mathrm{~m}$ & $94^{\circ} \mathrm{C}, 10 \mathrm{sec}$ & $48.8^{\circ} \mathrm{C}, 10 \mathrm{sec}$ & $72^{\circ} \mathrm{C}, 8 \mathrm{~m}$ \\
\hline
\end{tabular}




\section{RESULTS AND DISCUSSION}

\section{Polymorphisms in the exon 4 and exon6 of mink pit-1}

gene: The PCR product was $117 \mathrm{bp}$ in length in exonl of mink pit-1 gene (Fig. 1), there no polymorphism was found in exonl.

The PCR products was $150 \mathrm{bp}$ in length in exon 4 of mink pit-1 gene (Fig. 2), three unique SSCP genotypes were observed (Fig. 3). The SNP accordingly contributed to $\mathrm{AA}, \mathrm{AB}$ and $\mathrm{BB}$ genotypes and the frequencies of $\mathrm{A}$ and $\mathrm{B}$ of five populations were shown in Table 3 . In order to confirm this polymorphism, the PCR product of the polymorphic animal was sequenced. This polymorphism, consisting of a $\mathrm{C}$ fi $\mathrm{T}$ transition at codon 43 , leads to a change from threonine to methionine (Fig. 4).

The PCR products was $164 \mathrm{bp}$ in length in exon 6 of mink pit-1 gene (Fig. 5)the exon 6 of mink pit-1 gene, three unique SSCP genotypes were identified. The frequencies of $\mathrm{C}$ and $\mathrm{D}$ of five populations were showed in Table 4 , the PCR product of the polymorphic animal was also sequenced. This polymorphism, consisting of a $\mathrm{A}$ fi $\mathrm{G}$ transition at codon 143 , leads to a change from lysine to arginine.

\section{Association of PIT-1 gene SNPs with growth traits: Pit-1} gene polymorphisms in the exon4 of each population correlated to growth traits. The $43 \mathrm{C}>\mathrm{T}$ polymorphism had some influences with chest circumference $(p=0.170)$ of standard-pitchy mink, chest circumference $(p=0.123)$ and carcass weight $(\mathrm{p}=0.068)$ of coffee mink, body weight ( $p=0.196)$ of white mink, body length $(\mathrm{p}=0.152)$, chest circumference $(\mathrm{p}=0.094)$ and abdomen circumference $(\mathrm{p}=0.142)$ of black mink $(\mathrm{p}<0.2)$ and was significantly associated with carcass weight $(\mathrm{p}=0.010)$ of black mink, body length ( $\mathrm{p}=0.004$ ) of sapphire mink, body length $(\mathrm{p}=0.003)$ of black mink ( $<<0.05)$, Furthermore, coffee mink with the $\mathrm{AB}$ and $\mathrm{AA}$ genotypes had significantly

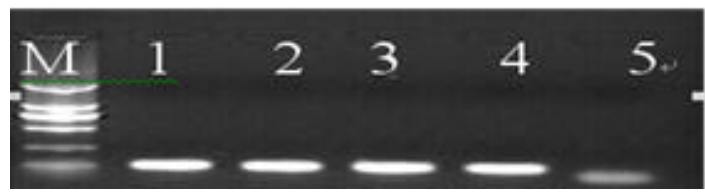

Fig. 1: PCR amplification results of primer 1 (primer 1) 1-4: PCR products; 5: control; M: DL 2000

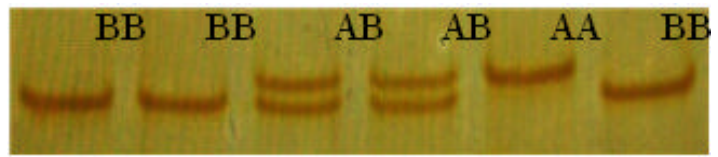

Fig. 2: PCR-SSCP results of different genotype
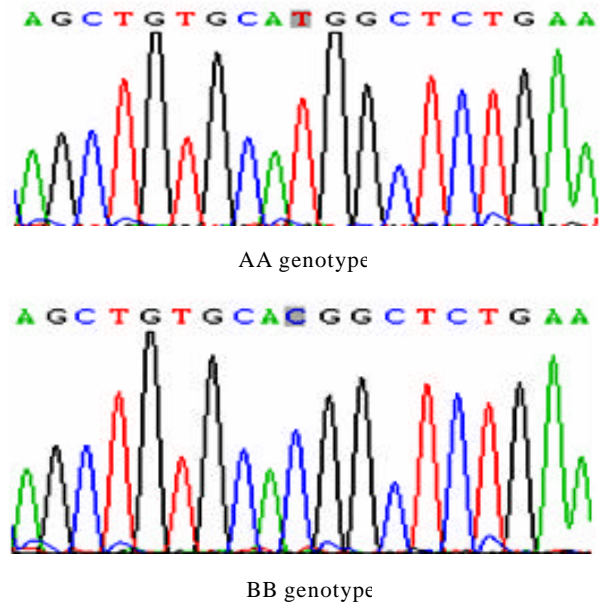

Fig. 3: Sequencing results of mutational site of exon 4 of PIT-1 gene

Table 3: Genotypes and allele frequencies of the mutation $43 \mathrm{C}<\mathrm{T}$ of $P I T-1$ gene

\begin{tabular}{|c|c|c|c|c|c|c|}
\hline \multirow[b]{2}{*}{ Population } & \multirow[b]{2}{*}{ No. } & \multicolumn{3}{|c|}{ Genotype frequency } & \multicolumn{2}{|c|}{ Allele frequency } \\
\hline & & AA & $\mathrm{BB}$ & $\mathrm{AB}$ & A & $\mathrm{B}$ \\
\hline Standard-pitchy & 121 & $0.298(36)$ & $0.140(17)$ & $0.562(68)$ & 0.579 & 0.421 \\
\hline Coffee & 56 & $0.393(22)$ & $0.054(3)$ & $0.553(31)$ & 0.670 & 0.330 \\
\hline Sapphire & 45 & $0.356(16)$ & $0.067(3)$ & $0.578(26)$ & 0.644 & 0.356 \\
\hline White & 57 & $0.088(5)$ & $0.719(41)$ & $0.193(11)$ & 0.184 & 0.816 \\
\hline Black & 60 & $0.150(9)$ & $0.317(19)$ & $0.533(32)$ & 0.417 & 0.583 \\
\hline
\end{tabular}

Table 4: Genotypes and allele frequencies of the mutation $143 \mathrm{~A}<\mathrm{G}$ of $P I T-1$ gene

\begin{tabular}{|c|c|c|c|c|c|c|}
\hline \multirow[b]{2}{*}{ Population } & \multirow[b]{2}{*}{ No. } & \multicolumn{3}{|c|}{ Genotype frequency } & \multicolumn{2}{|c|}{ Allele frequency } \\
\hline & & $\mathrm{CC}$ & DD & $\mathrm{CD}$ & $\mathrm{C}$ & $\mathrm{D}$ \\
\hline Standard-pitchy & 115 & $0.270(31)$ & $0.139(16)$ & $0.591(68)$ & 0.565 & 0.435 \\
\hline Coffee & 58 & $0.241(14)$ & $0.345(20)$ & $0.414(24)$ & 0.448 & 0.552 \\
\hline Sapphire & 46 & $0.087(4)$ & $0.391(18)$ & $0.522(24)$ & 0.348 & 0.652 \\
\hline White & 56 & $0.821(46)$ & $0.018(1)$ & $0.161(9)$ & 0.902 & 0.098 \\
\hline Black & 54 & $0.685(37)$ & 0 & $0.315(17)$ & 0.843 & 0.157 \\
\hline
\end{tabular}


Table 5: Effects of $43 \mathrm{C}<\mathrm{T}$ mutation on $\mathrm{CC}$ and $\mathrm{CW}$ in sapphire mink

\begin{tabular}{lccc}
\hline Genotype & No. & $\mathrm{CC}(\mathrm{g})$ & $\mathrm{CW}(\mathrm{g})$ \\
\hline $\mathrm{AA}$ & 22 & $22.250 \pm 0.375^{\mathrm{a}}$ & $0.889 \pm 0.022^{\mathrm{ab}}$ \\
$\mathrm{AB}$ & 31 & $22.371 \pm 0.312^{\mathrm{a}}$ & $0.929 \pm 0.019^{\mathrm{a}}$ \\
$\mathrm{BB}$ & 3 & $20.167 \pm 1.092^{\mathrm{b}}$ & $0.788 \pm 0.057^{\mathrm{b}}$ \\
\hline
\end{tabular}

Table 6: Effects of $43 \mathrm{C}<\mathrm{T}$ mutation on $\mathrm{BL}$ in coffee mink

\begin{tabular}{lcc}
\hline Genotype & No. & BL (cm) \\
\hline AA & 16 & $36.437 \pm 0.288^{b}$ \\
AB & 26 & $36.384 \pm 0.201^{b}$ \\
BB & 3 & $38.666 \pm 0.333^{\mathrm{a}}$ \\
\hline
\end{tabular}

Table 7: Effects of 43C $<\mathrm{T}$ mutation on BW and CW in black mink

\begin{tabular}{lccc}
\hline Genotype & No. & BW (g) & CW (g) \\
\hline AA & 9 & $1.189 \pm 0.037^{\mathrm{a}}$ & $0.769 \pm 0.016^{\mathrm{a}}$ \\
$\mathrm{AB}$ & 32 & $1.047 \pm 0.032^{\mathrm{b}}$ & $0.706 \pm 0.017^{\mathrm{b}}$ \\
$\mathrm{BB}$ & 19 & $1.209 \pm 0.037^{\mathrm{a}}$ & $0.778 \pm 0.017^{\mathrm{a}}$ \\
\hline
\end{tabular}

Table 8: Effects of $143 \mathrm{~A}<\mathrm{G}$ mutation on $\mathrm{BL}$ in sapphire mink

\begin{tabular}{lcc}
\hline Genotype & No. & BL (cm) \\
\hline CC & 4 & $37.750 \pm 0.947^{\mathrm{a}}$ \\
CD & 24 & $36.375 \pm 0.215^{\mathrm{b}}$ \\
DD & 18 & $36.388 \pm 0.244^{\mathrm{b}}$ \\
\hline
\end{tabular}

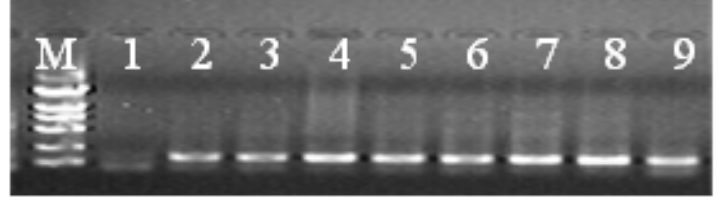

Fig. 4: PCRamplification results of primer 3(Primer 3) 2-9: PCR products; 1: control; M: DL 2000

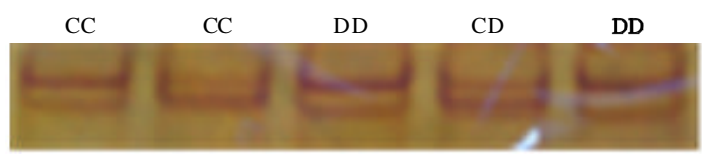

Fig. 5: PCR-SSCP results of different genotype

higher $\mathrm{CC}$ than the $\mathrm{BB}$ genotype and coffee mink with $\mathrm{AB}$ genotype had significantly higher $\mathrm{CW}$ as to minks harboring $\mathrm{AB}$ or $\mathrm{AA}$ genotypes (Table 5). For the sapphire mink, the BB genotype was associated with significantly higher $\mathrm{BL}$ as compared to minks harboring the $\mathrm{AA}$ and $\mathrm{AB}$ genotypes (Table 6). Moreover, the black mink with $\mathrm{BB}$ and $\mathrm{AA}$ genotypes were associated with significantly higher $\mathrm{BW}, \mathrm{CW}$ than in minks with $\mathrm{AB}$ (Table 7).

The $143 \mathrm{~A}>\mathrm{G}$ polymorphism had some influences with body length $(\mathrm{p}=0.079)$ of sapphire mink, abdomen circumference $(p=0.187)$ of white mink, body weight $(\mathrm{p}=0.183)$ and carcass weight $(\mathrm{p}=0.127)$ of black mink $(\mathrm{p}<0.2)$, the polymorphism was significantly associated with body length $(p=0.032)$ of black mink $(p<0.05)$. Furthermore, sapphire mink with the CC genotype had significantly higher $\mathrm{BL}$ than the $\mathrm{CD}$ or $\mathrm{DD}$ genotypes (Table 8). In black mink, only two genotypes were
Table 9: Effects of $143 \mathrm{~A}<\mathrm{G}$ mutation on BL in black mink

\begin{tabular}{llc}
\hline Genotype & No. & BL (cm) \\
\hline CC & 37 & $31.878 \pm 0.269^{b}$ \\
CD & 17 & $32.941 \pm 0.406^{\mathrm{a}}$ \\
\hline
\end{tabular}

Table 10: Multiple comparison of different genotype combination in sapphire mink

\begin{tabular}{lcc}
\hline Genotype & No. & $\mathrm{AC}(\mathrm{g})$ \\
\hline AACC & 4 & $27.125 \pm 1.434^{\mathrm{ab}}$ \\
AACD & 16 & $28.219 \pm 0.664^{\mathrm{a}}$ \\
AADD & 14 & $29.286 \pm 0.784^{\mathrm{a}}$ \\
ABCC & 16 & $28.906 \pm 0.713^{\mathrm{a}}$ \\
ABCD & 47 & $27.915 \pm 0.321^{\mathrm{ab}}$ \\
ABDD & 2 & $25.000 \pm 0.500^{\mathrm{b}}$ \\
BBCC & 11 & $27.409 \pm 0.642^{\mathrm{ab}}$ \\
BBCD & 5 & $27.000 \pm 1.140^{\mathrm{ab}}$ \\
\hline
\end{tabular}

Table 11: Multiple comparison of different genotype combination in genotype combination in standard-pitchy mink

\begin{tabular}{lrlc}
\hline Genotype & No. & BL $(\mathrm{cm})$ & BH $(\mathrm{cm})$ \\
\hline AACD & 3 & $36.667 \pm 0.667^{\mathrm{bc}}$ & $12.667 \pm 0.667^{\mathrm{bb}}$ \\
AADD & 13 & $36.385 \pm 0.331^{\mathrm{bc}}$ & $13.077 \pm 0.383^{\mathrm{a}}$ \\
ABCC & 2 & $35.000 \pm 0.000^{\mathrm{c}}$ & $13.000 \pm 0.000^{\mathrm{a}}$ \\
ABCD & 21 & $36.333 \pm 0.232^{\mathrm{bc}}$ & $13.548 \pm 0.223^{\mathrm{a}}$ \\
ABDD & 2 & $37.000 \pm 0.000^{\mathrm{b}}$ & $11.000 \pm 0.000^{\mathrm{b}}$ \\
BBCC & 3 & $38.667 \pm 0.333^{\mathrm{a}}$ & $14.333 \pm 0.882^{\mathrm{a}}$ \\
\hline
\end{tabular}

detected and the $\mathrm{CD}$ genotype had significantly higher BL as to minks harboring CC genotypes (Table 9).

Association of genotype combination with growth traits: The genotype combination had some influences with abdomen circumference $(\mathrm{p}=0.162)$ of standard-pitchy mink, body height $(\mathrm{p}=0.173)$ of sapphire mink, body length $(p=0.086)$ and body height $(p=0.078)$ of black mink $(\mathrm{p}<0.2)$. While the polymorphism was significantly associated with body length $(\mathrm{p}=0.026)$ of sapphire mink, carcass weight $(p=0.012)$ and body weight $(p=0.003)$ of black mink $(\mathrm{p}<0.05)$. Furthermore, Standard-pitchy mink with AADD genotype had the highest $\mathrm{AC}$ with other genotype and had significantly higher $\mathrm{AC}$ than the $\mathrm{ABDD}$ genotype (Table 10). Sapphire mink with the BBCC genotype had significantly higher $\mathrm{BL}$ than the other five genotypes and the $\mathrm{BBCC}$ genotype had the highest $\mathrm{BH}$ which was associated with significantly higher $\mathrm{BH}$ as compared to minks harboring the $\mathrm{ABDD}$ genotype (Table 11) for the black mink, the AACD genotype was associated with significantly higher $\mathrm{BW}$ as compared to minks harboring the $\mathrm{ABCC}$ genotype, the $\mathrm{BBCD}$ genotype had significantly higher $\mathrm{BH}$ than the $\mathrm{AACD}$ and $\mathrm{ABCC}$ genotypes while the black mink with $\mathrm{BBCD}$ had significantly higher $\mathrm{CW}$ than the other five genotypes (Table 12).

Several studies identified polymorphisms of the Pit-1 gene and their associations with quantitative traits (Moody et al., 1996; Brunsch et al., 2002). In this study, we detect the polymorphism of the Pit-1 gene in five mink populations by PCR-SSCP and DNA sequencing methods 
Table 12: Multiple comparison of different genotype combination in black mink

\begin{tabular}{lcccc}
\multicolumn{5}{c}{ mink } \\
\hline Genotype & No. & BW $(\mathrm{g})$ & BH $(\mathrm{cm})$ & CW $(\mathrm{g})$ \\
\hline AACC & 3 & $1.117 \pm 0.011^{\mathrm{ab}}$ & $14.333 \pm 0.667^{\mathrm{ab}}$ & $0.725 \pm 0.020^{\mathrm{bc}}$ \\
AACD & 5 & $1.257 \pm 0.048^{\mathrm{a}}$ & $13.000 \pm 0.000^{\mathrm{b}}$ & $0.804 \pm 0.011^{\mathrm{b}}$ \\
ABCC & 17 & $0.099 \pm 0.034^{\mathrm{b}}$ & $13.029 \pm 0.279^{\mathrm{b}}$ & $0.684 \pm 0.021^{\mathrm{c}}$ \\
ABCD & 11 & $1.143 \pm 0.066^{\mathrm{ab}}$ & $13.727 \pm 0.407^{\mathrm{ab}}$ & $0.742 \pm 0.033^{\mathrm{bc}}$ \\
BBCC & 17 & $1.221 \pm 0.040^{\mathrm{a}}$ & $13.853 \pm 0.209^{\mathrm{ab}}$ & $0.772 \pm 0.018^{\mathrm{bc}}$ \\
BBCD & 2 & $1.180 \pm 0.000^{\mathrm{ab}}$ & $15.000 \pm 0.000^{\mathrm{a}}$ & $0.900 \pm 0.000^{\mathrm{a}}$ \\
\hline
\end{tabular}

to determine its contributions to growth traits. Researchers began the search for Pit-1 polymorphisms by using the SSCP technique which is considered a useful tool for preliminary DNA polymorphism studies. Sensitivity of this technique is negatively correlated with the length of the analyzed DNA fragment (Skorczyk et al., 2007); therefore, researchers devised three primers and generate fragments of sufficient length $(<250 \mathrm{bp})$ for detecting polymorphisms. By this approach, researchers only detected two polymorphisms within the exon4 and exon6 of mink Pit-1 gene that may significantly affect the growth traits associated with Pit-1 protein function. The results of least square analysis confirmed that a significant association existed between the $\mathrm{AB}$ genotype of coffee mink and abdomen circumference, carcass weight and between the $\mathrm{BB}$ genotype of sapphire mink and body length and between the $\mathrm{BB}$ genotype of black mink and body weight, carcass weight and between the CC genotype of sapphire mink and body length and between the CD genotype of black mink and body length while the exact mechanism underlying the growth trait associated polymorphisms detected in the study remains unclear.

According to the study, the polymorphisms of pit-1 gene have significant effect on the body weight, body length and carcass weight. Renaville et al. (1997) found a positive association of allele A of the POU1 F1 HinfI polymorphism with milk and protein yields in Holstein-Friesian dairy cattle. Interestingly, Zwierzchowski found no relationship of this marker with growth and carcass traits in beef cattle, the similar result was showed in Angus beef cattle (Zhao et al., 2004) which found no significant associations were observed between polymorphisms of pit-1 gene in Angus beef cattle and growth and carcass traits. Nie et al. (2008) found that polymorphisms of Pit-1 gene and their haplotypes were associated with chicken growth traits but not with carcass and fatty traits. However, Pan et al. (2008) also found no significant associations of the TaqI polymorphism of pit-1 gene with body weight and average daily gain for different growth periods $(6,12,18$ and 24 months old) were observed $(p<0.05)$ as well as for body sizes $(p<0.05)$. Therefore, this genetic marker seems to have different effects in different populations and species.
The relationship between candidate genes of polymorphic loci and traits can take advantage of haplotype analysis or genotype combination analysis. The research of the correlation between the human disease and gene showed that the linkage analysis of a few loci and traits was more accurate than the single loci (Schafer and Hawkins, 1998). The genotype combination was not a simple sum of the effect of each gene but slightly higher than the best single genotype effect (Chen et al., 2000). Haplotype analysis was used in chicken $H$-FABP gene by PCR-SSCP, the result showed that $H-F A B P$ gene haploid $\mathrm{AB}-\mathrm{AB}-\mathrm{BB}-\mathrm{BB}-\mathrm{AA}$ and $\mathrm{BB}-\mathrm{AB}-\mathrm{AB}-\mathrm{BB}-\mathrm{BB}$ with a higher Intramuscular Fat Content (IMF), the maximum effect value and the IMF which had significantly differences with the other genotypes was the best genotype combination (Wang, 2006). The combination genotype analysis was used in the research of the interaction of MC3R-T91G and MC4R-A903G in pigeon, the result showed that the combined genotype had significant association with holo-carcass weight $(\mathrm{p}<0.05)$. BBAA genotype birds had a higher holo-carcass weight than $\mathrm{AABB}$ genotype birds and BBAA genotype was the beneficial genotype for the growth of body weight (Li et al., 2008).

In this study, the interaction of $43 \mathrm{C}<\mathrm{T}$ mutation and $143 \mathrm{~A}<\mathrm{G}$ mutation in PIT-1 gene was discussed through combination genotype analysis. The result showed that the interactive effect of two SNPs was both positive and negative and irregularity. This is consistent with earlier study of the combination genotype analysis of five genes (ESR, FSH $\beta, P R L, P R L R$ and NCOA1) and little size in pigs (Shi et al., 2006). According to the study, $43 \mathrm{C}<\mathrm{T}$ polymorphism had some influence in abdomen circumference of standard-pitchy mink $(p<0.2)$ but there was no significant difference between different genotype and the $143 \mathrm{~A}<\mathrm{G}$ polymorphism had no influence in growth traits of standard-pitchy mink while the combination genotype analysis found that there was significantly association between the genotype and abdomen circumference which may be due to the positive effect of combination genotype. While in the study of coffee mink and white mink researchers found that both the $43 \mathrm{C}<\mathrm{T}$ and $143 \mathrm{~A}<\mathrm{G}$ polymorphism has some influence in some growth traits $(\mathrm{p}<0.2)$ but the result of combination genotype showed no correlation between the genotype and traits which may be the negative effect of combination genotype. In Sapphire mink, the result of combination genotype was consistent with single soci and the $\mathrm{BBCC}$ genotype had significantly higher $\mathrm{BL}$ than the $\mathrm{BB}$ genotype and $\mathrm{CC}$ genotype, the $\mathrm{BBCC}$ genotype was the preponderant genotype in body length of 
sapphire mink. The similar result was found in black mink, BBCD genotype was the preponderant genotype in body weight of black mink.

\section{CONCLUSION}

The study demonstrated that polymorphisms in exon 4 and exon 6 of mink pit-1 gene contribute to variance of growth traits in different populations. Thus, the pit-1 gene may be an important target of molecular breeding to mink.

\section{ACKNOWLEDGEMENTS}

Researchers would like to thank the members of the economic animal group at Northeast Agricultural University for their help in collecting the data used in the analysis. Fangyong-Ning contributed equally with Hongyan-Yang in this study.

\section{REFERENCES}

Bastos, E., I. Santos, I. Parmentier, J.L. Castrillo, A. Cravador, H. Guedes-Pinto and R. Renaville, 2006. Ovis aries POU1F1 gene: Cloning, characterization and polymorphism analysis. Genetica, 126: 303-314.

Bodner, M., J.L. Castrillo, L.E. Theill, T. Deerinck, M. Ellisman and M. Karin, 1988. The pituitary-specific transcription factor GHF-1 is a homeobox-containing protein. Cell, 55: 505-518.

Brunsch, C., I. Sternstein, P. Reinecke and J. Bieniek, 2002. Analysis of associations of PIT1 genotypes with growth, meat quality and carcass composition traits in pigs. J. Applied Genet., 43: 85-91.

Chen, K.F., L.S. Huang, N. Li, Q. Zhang and J.S. Zhang et al., 2000. Effects between combination genotype FSHá and ESR gene and litter size in pig. Chin. Sci. Bull., 45: 1963-1966.

Cohen, L.E. and S. Radovick, 2002. Molecular basis of combined pituitary hormone deficiencies. Endocr. Rev., 23: 431-442.

Cohen, L.E., F.E. Wondisford and S. Radovick, 1996. Role of pit-1 in the gene expression of growth hormone, prolactin and thyrotropin. Endocrinol. Metab. Clin. North Am., 25: 523-540.

Ingraham, H.A., R.P. Chen, H.J. Mangalam, H.P. Elsholtz and S.E. Flynn et al., 1988. A tissue-specific transcription factor containing a homeodomain specifies a pituitary phenotype. Cell, 55: 519-529.

Jiang, R., J. Li, L. Qu, H. Li and N. Yang, 2004. A new single nucleotide polymorphism in the chicken pituitary-specific transcription factor (POU1F1) gene associated with growth rate. Anim. Genet, 35: $344-346$.
Lan, X.Y., J.H. Shu, H. Chen, C.Y. Pan and C.Z. Lei et al., 2009. A PstI polymorphism at 3'UTR of goat POU1F1 gene and its effect on cashmere production. Mol. Biol. Rep., 36: 1371-1374.

Li, S.P., Z.H. Du, F.Y. Ning, H.X. Sun and X.J. Bai, 2008. Correlation analysis between $M C 3 R$ and MC4R gene polymorphism and growth traits in pigeon. Yi Chuan., 30: 1333-1340.

Moody, D.E., D. Pomp, S. Newman and M.D. MacNeil, 1996. Characterization of DNA polymorphisms in three populations of Hereford cattle and their associations with growth and maternal EPD in line 1 herefords. J. Anim. Sci., 74: 1784-1793.

Nie, Q.H., M.X. Fang, L. Xie, M. Zhou and Z. Liang et al., 2008. The PIT1 gene polymorphisms were associated with chicken growth traits. BMC Genet., Vol. 9. 10.1186/1471-2156-9-20.

Ohta, K., Y. Nobukuni, H. Mitsubuchi, T. Ohta and T. Tohma et al., 1992. Characterization of the gene encoding human pituitary-specific transcription factor, Pit-1. Gene, 122: 387-388.

Pan, C.Y., X.Y. Lan, H. Chen, Y.K. Guo, J.H. Shu, C. Lei and $\mathrm{X}$. Wang, 2008. A TaqI PCR-RFLP detecting a novel SNP in exon 2 of the bovine POU1F1 gene. Biochem. Genet., 46: 424-432.

Qun, F.F., Q.H. Nie, W.G. Jin, J.H. Ouyang, S.M. Lin, H. Sun and X.Q. Zhang, 2006. Association of a $57 \mathrm{bp}$ indel in chicken PIT-1 gene with growth and carcass traits. Acta Agric. Uni. Jiangxiensis, 28: 284-288.

Renaville, R., N. Gengler, E. Vrech, A. Prandi and S. Massart et al., 1997. Pit-1 gene polymorphism, milk yield and conformation traits for Italian HolsteinFriesian bulls. J. Dairy Sci., 80: 3431-3438.

Schafer, A.J. and J.R. Hawkins, 1998. DNA variation and the future of human genetics. Nat. Biotechnol., 16: 33-39.

Shi, Q.S., X.C. Liu, Z.W. Liu, X.P. Li, Y.H. Li and F. Tang, 2006. Effect of five genetic Loci related to pig litter size. Yi Chuan., 28: 652-658.

Skorczyk, A., M. Stachowiak, I. Szczerbal, J. KlukowskaRoetzler, C. Schelling, G. Dolf and M. Switonski, 2007. Polymorphism and chromosomal location of the MC4R (melanocortin-4 receptor) gene in the dog and red fox. Genetics, 392: 247-252.

Wang, Y., 2006. PCR-SSCP analysis of heart type fatty acid-binding protein gene and association with fat traits in chincken. M.A. Thesis, Sichuan Agricultural University China.

Zhao, Q., M.E. Davis and H.C. Hines, 2004. Associations of polymorphisms in the Pit-1 gene with growth and carcass traits in Angus beef cattle. J. Anim. Sci., 82: 2229-2233. 